\title{
Nathalie Dessens, Creole City. A Chronicle of Early American New Orleans Nathalie Dessens, From Saint-Domingue to New Orleans. Migration and Influences
}

\section{Claude Chastagner}

\section{OpenEdition}

\section{Journals}

\section{Electronic version}

URL: https://journals.openedition.org/transatlantica/7367

DOI: 10.4000/transatlantica.7367

ISSN: $1765-2766$

Publisher

Association française d'Etudes Américaines (AFEA)

\section{Electronic reference}

Claude Chastagner, "Nathalie Dessens, Creole City. A Chronicle of Early American New Orleans Nathalie Dessens, From Saint-Domingue to New Orleans. Migration and Influences", Transatlantica [Online], 1 | 2015, Online since 27 October 2015, connection on 01 February 2023. URL: http:// journals.openedition.org/transatlantica/7367 ; DOI: https://doi.org/10.4000/transatlantica.7367

This text was automatically generated on 1 February 2023.

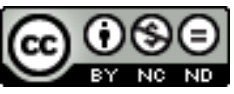

Creative Commons - Attribution-NonCommercial-NoDerivatives 4.0 International - CC BY-NC-ND 4.0 https://creativecommons.org/licenses/by-nc-nd/4.0/ 


\title{
Nathalie Dessens, Creole City. A Chronicle of Early American New
} Orleans

\section{Nathalie Dessens, From Saint- Domingue to New Orleans. Migration and Influences}

\author{
Claude Chastagner
}

\section{REFERENCES}

DESSENS, Nathalie, From Saint-Domingue to New Orleans. Migration and Influences, Gainesville, University Press of Florida, 2007 (cloth), 2010 (paperback), 257 p., 978-0-8130-3567-3, $65 € / 27.95$ \$

DESSENS, Nathalie, Creole City. A Chronicle of Early American New Orleans, Gainesville, University Press of Florida, 2015 (cloth), 273 p., 978-0-8130-6020-0, 74.95 \$

1 Book after book, Nathalie Dessens continues her exploration and analysis of the connections between the American South, more specifically Louisiana and New Orleans, and the Caribbean sphere. Her first opus, Myths of the Plantation Society: Slavery in the American South and the West Indies, released in 2004, had already broached the subject via the prism of slavery. The following two, From Saint-Domingue to New Orleans. Migration and Influences and Creole City. A Chronicle of Early American New Orleans, focus on the daily lives of New Orleanians in the early days of the Republic, from the perspective of the refugees who fled the Saint-Domingue slave rebellions of 1791 and after. Though the former is already a few years old, I believe they deserve to be reviewed here conjointly, since they offer a complementary vision of the city and its inhabitants at a 
crucial period of its history. From Saint-Domingue is indeed a study of the impact made on the city by the community of refugees who eventually settled in Louisiana in the aftermath of the Haitian revolution, a community which included the white population, the blacks slaves, as well as the intermediary category of free Blacks, often of mixed African descent. Creole City concentrates on the same community, and is based on the processing of numerous letters sent to a friend in France by a former inhabitant of Saint-Domingue who had relocated to New Orleans. Both books, however, are not restricted to the refugees' community, and they explore its connection with, and influence on the broader New Orleanian society, moving fluidly from political to economic, and cultural issues.

\section{Summary}

2 From Saint-Domingue is constructed along a chronological axis. Its first chapters deal with the slave rebellion on the island of Saint-Domingue and diaspora that followe, of most of its non-enslaved black population, and their eventual relocation first in other Caribbean islands, mainly Cuba and Jamaica, and later in New Orleans. Chapter one, a historical survey, details the state of the French colony before the rebellion, with due emphasis on its demographics, social order, and economy. Dessens shows how most of the traits that characterize the refugees and that will come to embody the spirit of New Orleans, its resilience, its entrepreneurial dynamism and a marked taste for the arts, and intellectual debates, were already present on the island and characterized its inhabitants. She then explores the roots of the slave rebellion, and the shifting alliances it generated, stressing the extent to which the island was in fact the nucleus of a web of complex economic and political exchanges. As the second chapter shows, the Haitian revolution triggered further displacements, eventually leading, for various reasons Dessens details, to the relocation in the early years of the $19^{\text {th }}$ century of a population nearing 15,000 people to the hitherto provincial, almost frontier town of New Orleans, reinforcing its cultural exception, and its effort to distance itself from the rest of the United States. Dessens gives a precise account of their reception by, and integration into New Orleans' Creole society, before focusing, in the third chapter, on the social make-up of the refugee population, particularly the distinct three classes of Whites, free Blacks of color, and Black slaves that make it up, so different from the twotiered Anglo society, a fact that will have dire consequences for the intermediary class of free Blacks once emancipation was proclaimed. A characteristic of Dessens's analysis is that it devotes an equal and simultaneous amount of interest to the three classes, since their practices "are best studied without differentiating the communities" (147). She emphasizes how the definite social, and cultural patterns of the three classes of refugees, originally fairly heterogeneous, eventually blended into a common, Creole identity, with strong inter-group links and a marked solidarity. The community nevertheless also mixed into the larger New Orleans society though retaining its distinctive features, a process which suggests "a syncretic culture emerging from the long coexistence of the several ethnic groups in Louisiana" (63).

3 The last four chapters deal with the various specific dimensions of the refugees' contribution, respectively in terms of economic, social, political, and cultural influence. The community was fairly successful on the whole (Dessens talks of a "success story", 69), and particularly so in medicine, agriculture, and skilled crafts, including sugar 
making. Their tastes for cultural and artistic activities led them to open theaters, opera houses, Masonic lodges. They launched newspapers, ballet companies, and schools, even for the free people of color. They wrote plays and novels, and altogether, exerted an influence on fashion, architecture, religion, food and of course the local language. On the social level, the three-class structure of the refugees "reinforced the Louisianans' resistance to the rigid racial order that the new American owners were trying to impose" (99). The community also enhanced the Catholic complexion of the city, and contributed to refining the local mores and reinforcing practices such as (sometimes legally sanctioned) unions between women of color and white men. The white refugees were initially considered politically dangerous, a situation Dessens explains by exploring the contrast between the Louisiana psyche and the revolutionary aura of the French-speaking community. Even if this initial distrust eventually subsided, there remains the fact that the Saint-Domingue refugees contributed to shaping Louisianan political activism and ideological make-up.

4 Creole City is complementary to the previous book, since it consists of the exploration, analysis, and commentary of the 158 letters (1200 pages) Jean Boze, a Frenchman who had lived for many years in Saint-Domingue before relocating to New Orleans, sent over a period of twenty years to his friend, Henri de Sainte-Gême, who after spending part of his life on the island and in New Orleans had permanently moved back to his family estate in France (the author of these letters, incidentally, is already mentioned in From Saint-Domingue). Organized with the same methodical and logical neatness as the former, along thematic chapters (which bear however, more evocative and stylish titles: "Adventure", "Extremes", "Progress", "Crossroads", "Cultures") Creole City reorganizes the content of these letters in order to give a portrait, and trace the evolution of New Orleans in the early years of the Republic from the perspective of a Saint-Domingue refugee. Such a specific prism is however not a restriction since it allows for a vivid rendering of many aspects of daily life in the Crescent City (all the more so as Boze frequently quotes newspapers articles, or hearsay). Besides, the background of both the author, and the recipient of the letters imply that the city is often inscribed within the larger scope of the Caribbean world, the transatlantic experience, and the European connections. Altogether, such letters lead to the emergence of what Dessens posits as her central thesis: "the porosity of the colonial worlds of the Americas and of the Atlantic space" (1). The period during which the letters were written is all the more important as it corresponds to a period of momentous and swift changes in New Orleans, when the various communities that inhabited the city initiated a process of increasing interaction Dessens describes as "Creolization".

5 The first chapter quite logically recalls the life history of the protagonists, insisting on the extent to which they both had, like many others, already crisscrossed the Atlantic Ocean and the Caribbean area extensively. Chapters 2 and 3 examine respectively the rudimentary living conditions in New Orleans, and "the march to progress" (2). Life was dangerous in New Orleans: a hostile environment (storms, droughts, floods, fires), disease (yellow fever and cholera), inadequate sanitation, traffic accidents, crime and violence, including numerous duels. There were also numerous crooks ready to embezzle local merchants. However, modernity was progressively improving living conditions. Streets were being paved, public lighting was expanding. Water, sewer, and transportation systems were progressively developed. Trade flourished (though there was also a series of crises, followed by many bankruptcies), which in turn led to a 
booming real estate and entertainment sector. The next chapter deals with the growing role New Orleans played in the Atlantic world. Boze describes it as a city of exchanges, still strongly connected to Europe (and of course, France particularly), but increasingly "firmly implanted in the United States and on the American continent" which led to "its repositioning in the Greater Caribbean and, more generally, in the Americas" (119). Understandably, the connection between New Orleans and France makes up for a sizeable portion of Boze's correspondence, and Dessens uses it to draw an extremely interesting picture of the political, legal, and diplomatic issues of the time. Nevertheless, despite being still very French, New Orleans' inhabitants were increasingly drawn into the young republic's interests, including its relations with neighboring countries, Cuba, Jamaica, Haiti, and even Latin America, mainly Mexico. The penultimate chapter focuses on social issues, and relying on Boze's accounts, draws a multiracial, multiethnic image of the city, noting the frequent inter-group cooperation, far from the customary descriptions in terms of binary oppositions and rivalries. Many communities, French-speakers of various origins, Germans, Hispanics, Swiss, and Irishmen lived side by side in what remained essentially a slave society, "a normal fact of life" for a large majority of the New Orleans people (151), Boze for one. And if he occasionally expresses a negative comment on the institution, it was mostly because of the bad influence of the recent influx of English-speaking slaves. Dessens devotes a long analysis to the three-tiered system and its various social and legal consequences, a normal feature to the Gallic and Spanish people of New Orleans with which Boze finds no fault, contrary to the Anglo-Saxon Americans. One conspicuous absence in Boze's letters, though, are Native Americans, who were nevertheless very present in the urban landscape. Dessens also deals extensively with the struggle (or competition) described by Boze between Creoles and Americans (and occasionally, the refugees). Like its predecessor, the book culminates with the gradual process of Creolization that characterized the city, this time through Boze's eyes. The rich mix of cultures and nationalities resulted in many different sounds, sights, religious creeds, artistic and cultural customs becoming increasingly cohesive, each community taking the best of what the others could offer, from legal systems, and languages to food and public celebrations. Which allows Dessens to conclude that increasingly, "New Orleans reacted as a community and no longer along ethnic or linguistic lines" (208), a "recreolization" process which built on the exiting blend of Native, African, and European traditions.

6 Both books contain 30 to 50 pages of detailed notes, followed by up-to-date bibliographies and webographies. A sample letter by Boze, in French, with its translation into English complements Creole City, as well as 10 illustrations.

\section{Discussion}

7 The breadth of Nathalie Dessens's knowledge of the history of this part of the world is properly stunning, as much as her ability to leave the region to encapsulate its fate within the broader perspective of the Caribbean sphere, the Americas, the United States, and even Europe. World history, geography, and economy are summoned to explain local developments, as she weaves the various threads of her narrative. She manages to give both an extremely detailed, intricate account of life during the early days of the Republic in the swiftly transforming city of New Orleans, making us 
appreciate the Creole specificity of the city, while never forgetting the bigger picture. Similarly, she focuses, from a New Social History perspective, on the existence and experiences of humble people, and their everyday preoccupations, as much as on the political and economic leaders and decision makers. Her books abound with precise figures, statistics, facts, names, which allow for easy comparisons with other periods or places, but never obfuscate their broader significance. Her unobtrusive, elegant, jargon-free prose allows for pleasant reading, all the more so as Dessens has the courtesy of providing the reader, for each chapter, with clear introductions, and precise intermediary and final recapitulations.

8 One very slight regret, the consequence probably of the qualities mentioned above, is that Nathalie Dessens deals very little with theoretical issues, neither the "rich methodologies for the study of correspondence" she alludes to (Creole 2), nor the more momentous questions of creolization and the related concepts such as syncretism, hybridization, or amalgamation. Dessens states that she prefers, rather than discuss them theoretically, to apply them to the case of the refugees (From Saint-Domingue 3). But although she devotes the concluding pages of both books to the specific nature of the creolization process implemented by the Saint-Domingue refugees, flavored by Caribbean and Gallic influences, she does not perhaps engage sufficiently with the contemporary debates these concepts have given rise to and the extent to which they can be relevant or not to the New Orleans paradigm. I refer here for instance to the "liquid" theories of Zygmunt Bauman, or the questioning of "hybridization" by anthropologists such as Jean-Loup Amselle on the grounds that it posits "untainted", discrete original cultures and ethnic "purity", to the risk of not only historical inaccuracy, but also of cultural essentialism and differentialism. Others, like Sidney M. Mintz, claim that these concepts cannot be used outside historically or geographically specific areas such as the Caribbean sphere properly speaking. Also, many cultural thinkers use "creolization" in the sense of giving a voice to those who were deprived of one, which turns the concept into a political tool, an instrument against ideological and political oppression and domination, a possibility Dessens does perhaps not take sufficiently into account. So that eventually, to quote from Sara Le Menestrel's latest book, using the concept of "creolization" as an analytical category becomes problematic (24).

9 But this is a very minor quibble in view of the wealth of information and perceptive analyses Dessens delivers. These two additions to the existing literature will definitely become landmarks, providing both original data, and fresh perspectives, particularly her focus on the seminal role the Haitian refugees played in giving New Orleans its distinctive Gallic Creole flavor. And to end on a more personal touch, I am very grateful to Nathalie Dessens for quoting zydeco music as "the best illustration of creolization in Louisiana" (Creole City 167). 


\section{BIBLIOGRAPHY}

AMSELLE, Jean-Loup, Branchements. Anthropologie de l'universalité des cultures, Paris, Flammarion, 2001.

BAUMAN, Zygmunt, Liquid Modernity, Cambridge, Polity, 2000.

LE MENESTREL, Sara, Negotiating Difference in French Louisiana Music. Categories, Stereotypes, and Identifications, Jackson, University Press of Mississippi, 2015.

\section{AUTHORS}

\section{CLAUDE CHASTAGNER}

Université Paul-Valéry Montpellier 3 